\title{
Bioaccumulation of potentially toxic elements in fish species from aquatic environments located in crowded areas of southern Romania
}

\author{
P Ionescu ${ }^{1,2}$, V M Radu ${ }^{1,2 *}$, Gy Deak ${ }^{1}$, I E Ciobotaru ${ }^{1}$, E Marcu ${ }^{1}$, E Diacu ${ }^{2}$ and M \\ Pipirigeanu $^{1}$ \\ ${ }^{1}$ National Institute for Research \& Development in Environmental Protection, Spl. \\ Independentei No. 294, $6^{\text {th }}$ District, Bucharest, Romania \\ ${ }^{2}$ University "Politehnica" of Bucharest, Faculty of Applied Chemistry and Materials \\ Science, 1-7 Polizu Street, 011061, Bucharest, Romania \\ *Corresponding author: radumonica33@yahoo.com
}

\begin{abstract}
Taking into consideration that fish are valuable bioindicators for assessing pollution with potentially toxic elements (PTEs) such as heavy metals from aquatic environments, this study aimed to assess bioaccumulation factors in relation to water (BAF) and sediment (BASF) for the following potential toxic elements: $\mathrm{Cd}, \mathrm{Pb}, \mathrm{Hg}, \mathrm{Cu}, \mathrm{Cr}, \mathrm{Ni}$ and $\mathrm{Zn}$ from 6 different fish species (Alburnus alburnus, Carassius gibelio, Scardinius erythrophthalmus, Ameiurus nebulosus, Perca fluviatilis, Lepomis gibbosus). Fish species have been captured from the waters of the Arges River (Hotarele village area) and the Colentina River (particularly from Mogosoaia, Herastrau and Panteliom lakes), from crowded areas located in the southern part of Romania. The results of the analysis indicated BAF values $>1$ for the most fish species captured from the Colentina River. BASF values $>1$ were obtained for BASF Pb $_{\text {(Carassius }}$ gibelio - Arges River), $\mathrm{BASF}_{\mathrm{Ni}}$ (Scardinius erythrophthalmus - Herastaru L. and Perca fluviatillis - Pantelimon L.), $\mathrm{BASF}_{\mathrm{Cr}}$ (Perca fluviatillis - Pantelimon L.) and $\mathrm{BASF}_{\mathrm{Zn}}$ (Alburnus alburnus and Scardinius erythrophthalmus - Mogosoaia L. and Carassius gibelio - Pantelimon L.). The obtained results can be used to describe the transfer of these elements from water and sediments to the fish tissue.
\end{abstract}

\section{Introduction}

At global level, the occurrence of toxic substances in the environment has raised concerns due to their direct toxicity on human health and aquatic environment and through their accumulation in the aquatic food chain $[1,2]$. Of these, heavy metals are a group of the most important pollutants in the environment as they are indestructible and most of them have toxic effects on organisms $[3,4,5,6$, $7,8]$. Due to the constant exposure of aquatic organisms to the chemical substances from contaminated water, different trophic levels and different size and age, fish is a good indicator for the contamination with potentially toxic elements (PTEs) $[9,10]$. Some heavy metals play an essential role in carrying out all the biochemical and energetic changes with a role in the living tissues, while others are highly toxic even at very low concentrations, causing numerous health problems $[11,12]$.

Unlike other metals, cadmium (Cd) is widely distributed at low levels in the environment and is not an essential element for humans, animals and plants [13]. Lead $(\mathrm{Pb})$ is also a non-essential, toxic element with no biological functions, that tends to accumulate in animal tissues [14]. Mercury ( $\mathrm{Hg}$ ) and its organic and inorganic compounds may be transferred in sediments by mutilation in the presence of 
microorganisms, with the formation of a toxic final product, methylmercury, able to penetrate the food chain and to bioaccumulate in the aquatic organisms $[15,16]$. Copper $(\mathrm{Cu})$ is an essential micronutrient necessary for growth and metabolism of all living organisms including fish, however at high concentrations it becomes one of the most toxic elements. Among its toxicity effects are damage to gills and necrosis to liver, growth depression [17]. Chromium $(\mathrm{Cr})$ is also an essential element for organisms, with the trivalent $\mathrm{Cr}$ having an essential role in glucidic metabolism. As regards the hexavalent $\mathrm{Cr}$, it is a toxic industrial pollutant and has been classified as carcinogen possessing mutagenic and teratogenic properties [18]. Zinc (Zn) is indispensable for growth and development of microorganisms, plants and animals, however excess levels may become toxic [19].

Uncontrolled development of constructions in urban areas, the lack of proper infrastructure and discharge of untreated municipal wastewaters is placing an unprecedented pressure on water quality and demand $[20,21]$. In this context, the study aimed to assess bioaccumulation factors in relation to water (BAF) and sediment (BASF) for the potential toxic elements $\left(\mathrm{PTE}_{\mathrm{s}}\right)$ such as $\mathrm{Cd}, \mathrm{Pb}, \mathrm{Hg}, \mathrm{Cu}, \mathrm{Cr}$, $\mathrm{Ni}$ and $\mathrm{Zn}$ from different fish species captured from aquatic environments located în the crowded areas from the southern part of Romania.

\section{Materials and Methods}

\subsection{Sample Source}

To achieve the study objective, fish, water and sediment, two sampling campaigns was organized in July 2016 and June 2018 on the Arges River and Colentina River (Mogosoaia, Herastrau and Pantelimon Lakes). Table 2 shows details about the sampling campaings.

Table 1. Sampling site locations.

\begin{tabular}{lccc}
\hline & \multicolumn{2}{c}{ Notation of sampling site locations } & Campaign/Year \\
\hline P1 & Arges River & Hotarele (village area) & II - 2018 \\
\hline P2 & & Mogosoaia Lake & \\
P3 & Colentina River & Herastrau Lake & I - 2016 \\
P4 & & Pantelimon Lake & \\
\hline
\end{tabular}

The water samples were collected in polyethylene recipients $(3 \mathrm{~L})$ from approximately $30 \mathrm{~cm}$ below water surface and were kept at $4{ }^{\circ} \mathrm{C}$ during their transport to the laboratory, according to the in force standards [22, 23, 24]. Sediment samples were collected according to sampling procedure of the current standards [25]. For achieving the aim of the study, fish specimens belonging to six species (Alburnus alburnus, Carassius gibelio, Scardinius erythrophthalmus, Ameiurus nebulosus, Perca fluviatilis, Lepomis gibbosus) were purchased from local fishermen. All samples were kept at $4{ }^{\circ} \mathrm{C}$ during their transport to the laboratory.

\subsection{Procedure}

The water samples was acidified to prevent hydrolysis of the metals, by adding nitric acid $(65 \%)$ in it [26]. Fish samples were gutted using a ceramic knife, skinless fillets and bone from the dorsal musculature were taken for analysis. Fish muscle tissue was dried to about $60{ }^{\circ} \mathrm{C}$ in the laboratory oven, milled to homogeneity in a non-metallic mortar. Microwave digestion system equipped with a temperature and pressure control was used to digest the fish samples. Approximately $0.5 \mathrm{~g}$ of sample were weighed and digested using a mixture of $7 \mathrm{~mL}$ of $65 \%$ nitric acid (Suprapur) and $3 \mathrm{~mL}$ of $30 \%$ hydrogen peroxide (Suprapur) using the microwave digestion system.

The sediments samples were air dried at room temperature. After drying, in order to obtain representative samples, they were milled, sieved and to bring the sediment samples to the solution, mineralization of about $0.5 \mathrm{~g}$ of the sample from the fraction $<63 \mu \mathrm{m}$ has been performed in the presence of aqua regia. 


\subsection{Equipments and Materials}

Samples were analysed using a High-Resolution Continuum source atomic absorption spectrometer HRCSAAS ContrAA 700 (Analytikjena) to determine the following PTEs: $\mathrm{Cd}, \mathrm{Pb}, \mathrm{Hg}, \mathrm{Cu}, \mathrm{Cr}, \mathrm{Ni}$ and $\mathrm{Zn}$. The quality of the results was compared with reference materials (BB422-fish muscle certified reference material for trace metals; HC 73962555-ICP multi-element standard solution IV; LGC 6187river sediment standard reference material). Analytical results of the quality control samples indicated a satisfactory performance of heavy metal detection within the range of certified values $(90 \%-110 \%)$. All reagents used in this study were of analytical grade and all glassware used was washed with nitric acid $1.5 \mathrm{~mol} / \mathrm{L}$ and rinsed in double distilled water and deionized water before use.

\section{Results and Discussion}

Within this study, the bioaccumulation of the potentially toxic elements in fish was quantified by means of bioaccumulation factor (BF) defined as the ratio between the concentration of the element in organism and the corresponding concentration in water and, respectively the sediments $[27,28,29$, 30]. The bioavailability of metals is one of the key factors that determine their accumulation in the aquatic organisms and it depends mainly on the physicochemical factors of both water and sediments including the water $\mathrm{pH}$, the redox potential, temperature, hardness and total organic content [31]. Sediments provide nutrients and habitat for fish and benthos and thus favour the bioaccumulation of heavy metals from water and sediments in the aquatic organisms [31]. BF was calculated to estimate PTEs accumulation behavior and this can be used to describe the transfer of these elements from water and sediments to the fish tissue. If the $\mathrm{BF}>1$, then the fish samples may be regarded as accumulators, a $\mathrm{BF}=1$ indicates no influence and if the $\mathrm{BF}<1$, then fish samples may be regarded as being excluders [32].

$$
\begin{gathered}
B A F=\frac{C_{b}}{C_{a}} \\
B S A F=\frac{C_{b}}{C_{S}}
\end{gathered}
$$

where:

$\mathrm{BAF}=$ the bioaccumulation factor biota - water $[\mathrm{L} / \mathrm{Kg}]$;

$\mathrm{BSAF}=$ the bioaccumulation factor biota - sediments (adimensionally);

$\mathrm{C}_{\mathrm{b}}=$ the concentration of metal in the biota $[\mathrm{mg} / \mathrm{Kg}]$;

$\mathrm{C}_{\mathrm{a}}=$ the concentration of metal in water $[\mu \mathrm{g} / \mathrm{L}]$;

$\mathrm{C}_{\mathrm{s}}=$ the concentration of metal in sediments $[\mathrm{mg} / \mathrm{Kg}]$.

For the investigated fish species, the bioaccumulation factors in biota reported to water and sediments were computed (Table 2). In general, the bioaccumulation factor biota - water (BAF) showed values higher than 1 for most of the species captured from the three lakes located on the Colentina River, except for: Alburnus alburnus - $\mathrm{P} 2$ for $\mathrm{BAF}_{\mathrm{Cd}}$, Alburnus alburnus - $\mathrm{P} 4$ for $\mathrm{BAF}_{\mathrm{Cu}}, \mathrm{BAF}_{\mathrm{Ni}}, \mathrm{BAF}_{\mathrm{Cd}}$, $\mathrm{BAF}_{\mathrm{Pb}}$ and Leopomis gibbous - $\mathrm{P} 2$ for $\mathrm{BAF}_{\mathrm{Pb}}$ which showed $\mathrm{BAFs}$ values less than 1. The BAFs for the fish species captured from the P1 were below 1.

As regards the bioaccumulation factor biota - sediments (BASF), values higher than 1 were obtained for: $\mathrm{BAF}_{\mathrm{Ni}}$ (Scardinius erythrophthalmus - $\mathrm{P} 3$ and Perca fluviatillis - $\left.\mathrm{P} 4\right) \mathrm{BAF}_{\mathrm{Pb}}$ (Carassius gibelio $\mathrm{P} 1$ ) and $\mathrm{BAF}_{\mathrm{Zn}}$ (Alburnus alburnus and Scardinius erythrophthalmus - P2 and Carassius gibelio - P4). 
Table 2. The bioaccumulation factors (BAF/BSAF)

of heavy metals from water and sediments to biota.

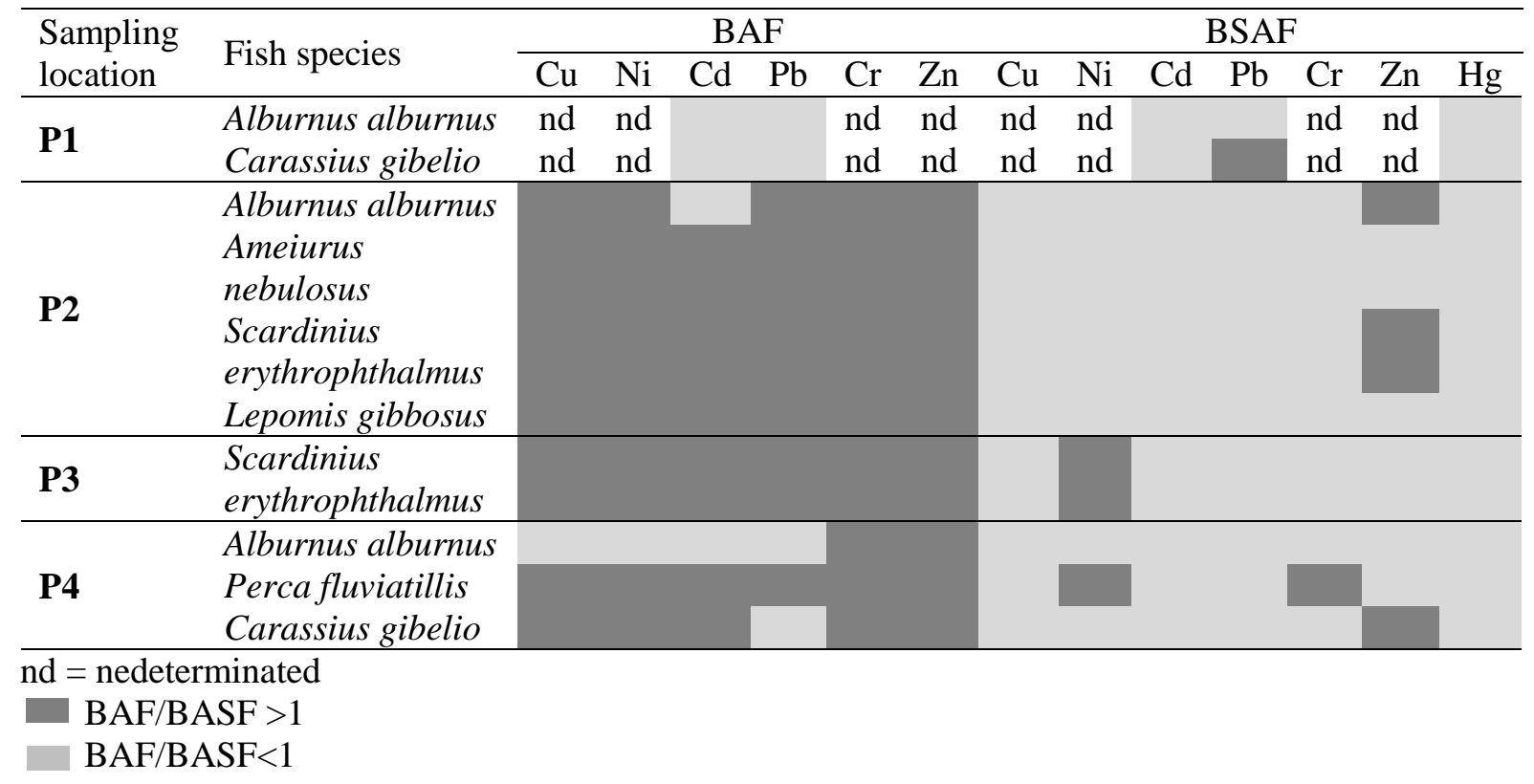

Based on the computed values of the bioaccumulation factor, the order in which the bioaccumulation of metals from water and sediments varies was obtained and it is shown in table 3 .

Table 3. Comparative analysis of the bioaccumulation factors.

\begin{tabular}{|c|c|c|c|}
\hline $\begin{array}{l}\text { Sampling } \\
\text { location }\end{array}$ & Fish species & BAF & BSAF \\
\hline \multirow{2}{*}{ P1 } & Alburnus alburnus & $\mathrm{Cd}>\mathrm{Pb}$ & $\mathrm{Hg}>\mathrm{Cd}>\mathrm{Pb}$ \\
\hline & Carassius gibelio & $\mathrm{Pb}>\mathrm{Cd}$ & $\mathrm{Pb}>\mathrm{Hg}>\mathrm{Cd}$ \\
\hline \multirow{4}{*}{ P2 } & Alburnus alburnus & $\mathrm{Zn}>\mathrm{Cr}>\mathrm{Pb}>\mathrm{Ni}>\mathrm{Cu}=\mathrm{Cd}$ & $\mathrm{Zn}>\mathrm{Hg}>\mathrm{Cr}>\mathrm{Pb}>\mathrm{Cd}>\mathrm{Cu}=\mathrm{Ni}$ \\
\hline & $\begin{array}{l}\text { Ameiurus } \\
\text { nebulosus }\end{array}$ & $\mathrm{Zn}>\mathrm{Pb}>\mathrm{Cr}>\mathrm{Cu}>\mathrm{Ni}>\mathrm{Cd}$ & $\mathrm{Hg}>\mathrm{Zn}>\mathrm{Pb}>\mathrm{Cd}=\mathrm{Cr}=\mathrm{Cu}>\mathrm{Ni}$ \\
\hline & $\begin{array}{l}\text { Scardinius } \\
\text { erythrophthalmus }\end{array}$ & $\mathrm{Zn}>\mathrm{Cr}>\mathrm{Pb}=\mathrm{Cu}=\mathrm{Ni}>\mathrm{Cd}$ & $\mathrm{Zn}>\mathrm{Hg}>\mathrm{Cr}=\mathrm{Pb}>\mathrm{Cd}=\mathrm{Cu}=\mathrm{Ni}$ \\
\hline & Lepomis gibbosus & $\mathrm{Zn}>\mathrm{Cr}>\mathrm{Pb}>\mathrm{Ni}>\mathrm{Cu}>\mathrm{Cd}$ & $\mathrm{Hg}>\mathrm{Zn}>\mathrm{Pb}>\mathrm{Cr}>\mathrm{Cd}=\mathrm{Ni}>\mathrm{Cu}$ \\
\hline $\mathbf{P 3}$ & $\begin{array}{l}\text { Scardinius } \\
\text { erythrophthalmus }\end{array}$ & $\mathrm{Ni}>\mathrm{Zn}>\mathrm{Cr}>\mathrm{Cd}>\mathrm{Cu}>\mathrm{Pb}$ & $\mathrm{Ni}>\mathrm{Cd}>\mathrm{Zn}>\mathrm{Hg}>\mathrm{Cr}>\mathrm{Cu}>\mathrm{Pb}$ \\
\hline \multirow{3}{*}{$\mathbf{P 4}$} & Alburnus alburnus & $\mathrm{Zn}>\mathrm{Cr}>\mathrm{Cu}>\mathrm{Ni}=\mathrm{Cd}>\mathrm{Pb}$ & $\mathrm{Ni}>\mathrm{Cd}>\mathrm{Zn}>\mathrm{Hg}>\mathrm{Cr}>\mathrm{Cu}>\mathrm{Pb}$ \\
\hline & Perca fluviatillis & $\mathrm{Cr}>\mathrm{Ni}>\mathrm{Zn}>\mathrm{Cd}>\mathrm{Cu}>\mathrm{Pb}$ & $\mathrm{Ni}>\mathrm{Cr}>\mathrm{Zn}>\mathrm{Cd}>\mathrm{Hg}>\mathrm{Cu}>\mathrm{Pb}$ \\
\hline & Carassius gibelio & $\mathrm{Zn}>\mathrm{Cr}>\mathrm{Cd}>\mathrm{Ni}=\mathrm{Cu}>\mathrm{Pb}$ & $\mathrm{Zn}>\mathrm{Cd}>\mathrm{Hg}>\mathrm{Cu}=\mathrm{Ni}>\mathrm{Cr}=\mathrm{Pb}$ \\
\hline
\end{tabular}

As it may be observed from table 3, the fish from P2 and P3 showed the tendency to bioaccumulate in muscle tissue mainly $\mathrm{Zn}, \mathrm{Cr}$ and $\mathrm{Pb}$ from water and $\mathrm{Zn}$ and $\mathrm{Hg}$ from sediments.

The European perch (Scardinius erythrophthalmus) captured from P3 had the tendency to accumulate $\mathrm{Ni}$ and $\mathrm{Zn}$ from water and $\mathrm{Ni}$ and $\mathrm{Cd}$ from sediments.

As regards the fish from the $\mathrm{P} 4$, the bleak (Alburnus alburnus) shows the tendency to biaccumulate Ni and $\mathrm{Zn}$ from water and $\mathrm{Ni}$ and $\mathrm{Cd}$ from sediments; the rudd (Perca fluviatillis) showed similar tendency for $\mathrm{Cr}, \mathrm{Ni}$ and $\mathrm{Zn}$ from water and sediments, and Carassius gibelio showed the tendency to bioaccumulate $\mathrm{Zn}, \mathrm{Cr}$ and $\mathrm{Cd}$ from water and $\mathrm{Zn}, \mathrm{Cd}$ and $\mathrm{Hg}$ from sediments. 


\section{Conclusions}

Contamination with potentially toxic elements such as heavy metals at the aquatic ecosystems is a major problem as they accumulate in the trophic chains. The analysis of BAF showed that values higher than 1 were highlighted for most of the fish species captured from the Colentina River. As regards the BASF, values higher than 1 were obtained for $\mathrm{BASF}_{\mathrm{Pb}}$ (Carassius gibelio - Arges River), BASF $_{\mathrm{Ni}}$ (Scardinius erythrophthalmus - Herastaru L. and Perca fluviatillis - Pantelimon L.), BASF $\mathrm{Cr}_{\mathrm{Cr}}$ (Perca fluviatillis - Pantelimon L.) and $\mathrm{BASF}_{\mathrm{Zn}}$ (Alburnus alburnus and Scardinius erythrophthalmus - Mogosoaia L. and Carassius gibelio - Pantelimon L.).

A high bioaccumulation potential does not necessarily imply a high toxicity potential, the situation being different depending on each element. Monitoring contamination with potentially toxic elements of the aquatic environment by assessing the bioaccumulation in the muscle tissue of fish is a useful tool in assessing the quality of aquatic ecosystems.

\section{Acknowledgments}

This work used data obtained through the MEVAS 48N/2016 (PN16040104) and MARES 43N/2018 (PN 18260102). The authors would like to thank the management and employees of National Institute for Research and Development in Environmental Protection for their valuable assistance and suggestions. Petra Ionescu's contribution was partially financed by the Operational Programme Human Capital of the Ministry of European Funds through the Financial Agreement 51668/09.07.2019, SMIS code 124705.

\section{References}

[1] Jiang Z, Xu N, Liu B, Zhou L, Wang J, Wang C, Dai B and Xiong W 2018 Ecotoxicol. Environ. Saf. 157 1-8

[2] Bravo A G, Loizeau J L and Dominik J 2010 Terre et Environnement 88 211-219

[3] Deák Gy, Dumitru F D, Moncea M A, Panait A M, Boboc M, Danalache T, Holban E, Marinescu F, Gheorghe P I, Ciobotaru I and Rozainy M R, 2019 AIP Conf. Proc. 5th International Conference on Green Design and Manufacture 2129 020067-1-5

[4] Radu V-M, Raischi S, Szep R, Tanase G S, Ionescu P 2015 Conf. Proc 15th International Multidisciplinary Scientific Geoconference (SGEM) Water resources, forest, marine and ocean ecosystems, June 18-24, Albena, Bulgaria $1277-283$

[5] Shakeri A, Shakeri R and Mehrabi B 2015 Int. J. Environ. Sci. Technol. 12 2201-2212

[6] Olteanu M, Baraitaru A, Dumitru D, Moncea A, Deák Gy, Butnariu C, Predescu C 2019 U.P.B. Sci. Bull., Series B 81 19-28

[7] McKinley K, McLellan I, Gagné F and Quinn B 2019 Science of the Total Environment 665 848-854

[8] Litaay M, Jehadum R V, Mardaranti R and Soekendarsi E 2018 IOP Conf. Series: Journal of Physics: Conf. Series 1116052039 doi:10.1088/1742-6596/1116/5/052039

[9] Milačič R, Zuliani T, Vidmar J, Bergant M, Kalogianni E, Smeti E, Skoulikidis N and Ščančar J 2019 Science of The Total Environment 648 1087-96

[10] Zuliani T, Vidmar J, Drinčić A, Ščančar J, Horvat M, Nečemer M, Piria M, Simonović P, Paunović M and Milačič R 2019 Science of the Total Environment 650 958-969

[11] Deák Gy, Daescu V, Holban E, Marinescu P, Tanase G S, Csergo R and Daescu A I, Gaman S 2015 Journal of Environmental Protection and Ecology 16 304-315

[12] Radu V M, Diacu E, Ionescu P and Ivanov A A 2017 U.P.B. Sci. Bull. Seria B 79 3-12

[13] Lane E A, Canty M J and More S J 2015, Research in Veterinary Science 101 132-39

[14] Jaishankar M, Tseten T, Anbalagan N and Mathew B B 2014 Interdiscip Toxicol. 7 60-72

[15] Svobodová Z, Lloyd R, Máchová J and Vykusová B 1993 Food and Agriculture Organization of the United Nations, EIFAC Technical Paper $\mathbf{5 4}$

[16] Martin S and Griswold P G 2009 Environmental Science and Technology Briefs for Citizens 15 1-6 
[17] Chanda S, Paul B N, Ghosh K and Giri S S 2015 Review 36 100-12

[18] Bakshi A and Panigrahi A K 2018 Toxicol Rep. 6 440-47

[19] Jan A T, Azam M, Siddiqui K, Ali A, Choi I and Haq Q M R 2015 Int. J. Mol. Sci. 16 29592630

[20] Ionescu P, Radu V M, Deák Gy, Diacu E, Marcu E and Ciobotaru I-E 2019, Rev. Chim. (Bucharest) 70 2889-96

[21] Radu V M, Diacu E, Moncea M A, Dumitru F D,. Panait A M and Ionescu P, Rev. Chim. (Bucharest), 2017, 68, 2477-81

[22] ***EN ISO 5667-1 2007 Water quality. Sampling. Part 1: Guidance on the design of sampling programmes and sampling techniques

[23] ***EN ISO 5667-3 2013 Water quality. Sampling. Part 3: Preservation and handling of water samples

[24] ***EN ISO 5667-6 2017 Water quality. Sampling. Part 6: Guidance on sampling of rivers and streams

[25] ***EN ISO 5667-12 2017 Water quality. Sampling. Part 12: Guidance on sampling of bottom sediments from rivers, lakes and estuarine areas

[26] ***SR ISO 8288/2001 Water quality. Determination of cobalt, nickel, copper, zinc, cadmium and lead. Flame atomic adsorption spectrometric methods

[27] Islam M S, Ahmed M K, Raknuzzaman M, Habibullah-Al-Mamun M and Masunaga S 2015 Arch. Environ. Contam. Toxicol. 68 92-106

[28] El-Moselhy KhM, Othman AI, Abd El-Azem H and El-Metwally M E A 2014 Egyptian Journal of Basic and Applied Sciences 1-9 (dx.doi.org/10.1016/j.ejbas.2014.06.001)

[29] Li M, Yang W, Sun T and Jin Y 2016 Marine Pollution Bulletin 103 227-239

[30] Ionescu P, Deák Gy, Diacu E and Radu V M 2016 Rev. Chim. (Bucharest) 67 2148-50

[31] Yi Y, Tang C, Yi T, Yang Z and Zhang S 2017 Ecotoxicol. Environ. Saf. 145 295-302

[32] Akkajit P, Fajriati P and Assawadithalerd M. 2018 Environmental science and pollution research international $2536147-57$ 